\title{
DIE VERHOUDING DOOP EN GELOOF
}

Prof. L. Floor

\section{DRIE BELANGRIKE VRAE}

By die aanvalle wat op die kinderdoop geloods word, kom telkens die verhouding doop en geloof ter sprake. Die geloof is so wesentlik met die doop verbonde, sodat daar nie gedoop mag word waar die geloof nie aanwesig is nie. Ons lees inderdaad dwarsdeur die Nuwe Testament van 'n innige samehang wat daar tussen geloof en doop besiaan.

A. D. R. Polman het daarop gewys dat ons in die Nuwe Testament duidelik 'n tweevoudige reeks van uitsprake aantref waarin aan die geloof en aan die doop dieselfde heilseffekte toegeskryf word. Aan die een kant lyk dit of net geloof die mens red, terwyl andersyds cie verlossing aan die doop verbind word (Polman, s.j.: 216). Ook $H$. N. Ridderbos is van oordeel dat nie alleen in die briewe van Paulus nie maar in die hele Nuwe Testament 'n noue verband tussen die doop en die geloof gelê word (1966: 458) en wel soveel so dat die geloof as 'n "mede-constituerende factor" van die doop beskou moet word (1966: 462).

Wanneer die cenheid van geloof en doop so onlosmaaklik is; mag daar dan wel gedoop word as daar soos by klein kindertjies nog nie geloof aanwesig is nie? Dwing die innige samehang van geloof en doop ons nie tot verwerping van die kinderdoop nie? Wat gebeur presies in die doop? Hier kom ons by ons eerste van drie belangrike vrae wat telkens in verband met die doop gevra word: wat verseël die doop? Is die Heilige Doop 'n seël op die belofte van God of is dit 'n seël op die geloof van die dopeling? Wanneer die Heilige Doop die geloof van die dopeling verseël dan moet ons alleen hulle doop wat hulle geloof bely het, dus volwassenes of ons moet die geloof by die kinders veronderstel.

'n Tweede belangrike vraag is die vraag na die volgorde van geloof en doop. Beteken die onlosmaaklike eenheid van geloof en doop dat ons van 'n chronologiese volgorde moet uitgaan: eers geloof en daarna die doop?

Op grond van Mark. $16: 16$ word deur die teenstanders van die kinderdoop so geredeneer. Die geloof gaan in tydsorde aan die doop vooraf. Derhalwe mag alleen iemand wat sy geloof bely het, gedoop word. Het ons in verhouding geloof - doop met 'n onomkeerbare volgorde te doen?

Om die tweede vraag te kan beantwoord moet ons teruggaan na die Ou Testament. Maar dit bring ons by ons derde belangrike vraag: mag ons in die diskussie oor die doop teurggaan na die $\mathrm{Ou}$ Testament. In die Ou Testament kom die verhouding geloof - besnydenis ter sprake. Maar mag ons hiervan gebruik maak? In die Gereformeerde tradisie is die kinderdoop altyd verdedig met die argument dat die doop in die plek van die besnydenis gekom het. By Calvyn is dit self die deurslaggewende argument.

Alle bewerings van die Anabaptiste, alle verwysings na die samehang van geloof en doop, alle argumente dat in die Nuwe Tes- 
tament geloof en geloofsbelydenis tog steeds aan die doop vooraf gaan, kon Calvyn nie oortuig nie. Hy erken dat daar in die Nuwe Testament telkens van die doop van die volwassenes gepraat word, maar die klein kindertjies behoort volgens Calvyn tot 'n ander kategorie (Inst. IV, VXI, 16-20).

In die gesprek oor die doop en met name die kinderdoop word telkens 'n beroep op die Bybel gedoen. Maar hier is dit die groot vraag op watter wyse ons ons op die Heilige Skrif beroep? Gaan ons by ons beroep op die Bybel uit van 'n teenstelling tussen die Ou en die Nuwe Testament of handhaaf ons die openbaringseenheid van die Heilige Skrif (Koopmans, 1939: 228)?

\section{BESNYDENIS EN GELOOF}

Ons begin by die vraag na die verhouding besnydenis - geloof omdat dit vanuit die Ou Testament lig werp op die verhouding doop - geloof in die Nuwe Testament.

Met 'n beroep op die slot van Mattheüs en Markus het die Anabaptiste telkens beweer dat die geloof en die geloofsbelydenis aan die doop vooraf behoort te gaan. Hier teenoor het Calvyn met nadruk gestel dat nie die geloof nie maar dat die leer aan die doop vooraf behoort te gaan. 'n Turk, 'n Jood of 'n heiden ontvang eers onderrig in die Christelike leer en daarna vind die doop plaas. So was dit reeds die gebruik in die Ou Testament en dan wys Calvyn op die voorbeeld van Abraham (Balke, 1973: 220).

Daar is egter volgens die bestryders van die kinderdoop in diepingrypende verskil tussen die $\mathrm{Ou}$ en die Nuwe Testament Die $\mathrm{Ou}$ Verbond is die bedeling van veroordeling en die dood, terwyl die Nuwe Verbond die bedeling van vergifnis, regverdig en lewe is (Beasley Murray, 1979: 340).

Die Doperse Beweging beskou die Ou Testament as minderwaardig ten opsigte van die Nuwe Testament. In die Ou Testament en onder die Ou Bedeling is alles aards en ligaamlik. God se heil vertuon in die Ou Testament soveel stoflike, aardse trekke dat dit nie as die volle heil beskou kan word nie.

In hul dualistiese benadering waarin die geestelike teenoor en bo die stoflike geplaas word, het die Doperse Beweging die Ou Testament as minderwaardig en verganklik teenoor die Nuwe Testament geplaas (Graafland, 1978: 23, 24).

In 'n studie van 'n sg. Gereformeerde baptis uit Australië het dit my ook weer getref dat die seëninge in die Ou Testament as stoflik, tvdelik en aards omskryf word. In die Ou Testament is slegs sprake van 'n natuurlike lidmaatskap van die verbond deur geboorte, terwyl dit in die Nuwe Testament gaan om 'n geestelike lidmaatskap deur wedergeboorte (Fowler, 1968: 7, 8).

Almal wat die kinderdoop verwerp kom op een of ander manier tot ' $n$ devaluering van die Ou Testament en die Ou Verbond. Die beslissing oor die kinderdoop al dan nie val by die waardering van die Ou Testament.

Die verwerpers van die kinderdoop sny die band tussen Ou en Nuwe Testament radikaai deur. Die doop het nie in die plek van 
die besnydenis gekom nie. As dit waar is dan kan die besnydenis ons mos niks oor die doop leer nie.

'n Joodse geleerde, David Flusser wat 'n professor is in die vergelvkende godsdienswetenskap aan die Hebreeuse universiteit te Jerusalem het in 'n indringende studie: Die Sakramente und das Judentum ip 'n onweerlegbare wyse aangetoon, dat die besnydenis sy voortsetting vind in die proselietedoop en die Christelike doop en die Pasga in die sakrament van die Heilige Nagmaal (Flusser, 1983: 3-18).

Calvyn het eeue gelede reeds dieselfde betoog. BY Calvyn is die verbond met die vaders 'in substantia et re' dieselfde as sy verbond met ons (Wolf, 1958: 23). Die verskil lê alleen in die wyse van bediening.

Terwyl die Doperse Beweging die verhouding van Ou en Nuwe Testament aandui as stoflik teenoor geestelik, kom Calvyn met die fyn onderskeiding van jeug teenoor manlike rypheid en volwassenheid (Komm. op Gal. $4: 1,2$ ).

In sy ksmmentaar op Gen. $15: 16$ trek Calvyn 'n parallel met Rom. 4. : 3 en dan skrywe hy dat Abraham ten volle in die regverdiging deur die geloof gedeel het en daarin gelyk staan met die gelowiges van die nuwe bedeling. Hier is ons by die kern van die saak. Die hele probleem van die verwerping van die kinderdoop draai om hierdie punt.

Soos daar in die Nuwe Testament 'n volwassenedoop is, so is daar in die Ou Testament 'n volwassenebesnydenis. Soos die dooppraktyk in die Nuwe Testament begin met die doop van volwassenes, so begin in die Ou Testament die besnydenispraktyk met die besnydenis van volwassenes, van gelowiges.

Die apostel Pulus stel dit nadruklik: Abraham is besny nadat hy tot geloof gekom het (Rom. $4: 10$ ).

Sy besnydenis is 'n teken en 'n seël van die geregtigheid van di geloof (Rom. 4:11). Die Besnydenis is vir Abraham 'n teken en 'n se 'n regte verhouding tot God.

Ons moet goed daarop let: nie sy geloof is deur sy besnydenis verseël nie, maar sy regte verhouding tot God wat alleen deur geloof ontvang kan word. Die geregtigheid wat net deur geloof ontvang kan word, staan teenoor 'n ander soort geregtigheid, naamlik 'n geregtigheid op grond van die werke van die wet (Fil. 3:9). Paulus plaas in Rom. 4 werkgeregtigheid teenoor geloofsgeregtigheid. Wat word dus in Abraham se besnydenis verseël? Nie Abraham se geloof nie, maar dit wat hy deur geloof ontvang het: die geregtigheid van God ook wel aangedui as die geregtigheid van Christus.

Paulus maak dit vir sy lesers in die brief aan die Romeine duidelik dat dit wat die besnydenis verseël, in verband gebring muet word met die heil wat Christus bewerk het. Die besnydenis het derhalwe betrekking op die heilswerklikheid van Christus. In die Ou Testament, in die tyd van Abraham het die heil in Christus nog 'n beloftekarakter gehad.

Die besnydenis is die seël van geloofsgeregtigheid. Dit beteken: die besnydenis is die waarborg dat die mens wat glo gered word. 
Die geloof is die instrument. Die genitief waarin die woord geloof in Rom. 4:11 staan is ' $n$ instrumentele genitief. Ons kan hierdie genitief selfs as 'n kwalifiserende of 'n deskriptiewe genitief aandiu. Dan word geloof hier deur Paulus kwalifiserend gebruik om die geregtigheid te omskrywe. Ons het hier met 'n bepaalde soort geregtigheid te doen naamlik geloofsgeregtigheid.

Ons beroof die besnydenis van sy geestelike karakter wanneer ons soos byvoorbeeld Karl Barth of die Anabaptiste die besnydenis maar net op die natuurlike geboorte betrek en daarin alleen maar 'n teken sien van die toebehore tot die verbondsvolk Israel.

\section{DIE VERRASSENDE OMKERING}

Hoewel die besnydenis van Abraham geheel en al 'n volwassenebesnydenis is, kry ons in die Ou Testament die merkwaardige verskynsel dat dieselfde besnydenis wat Abraham ontvang het en wat 'n teken en 'n seël van die geregtigheid van die geloof is, ook deur sy huis ontvang moet word.

Die volwassenebesnydenis gaan oor in 'n huisbesnydenis (Gen. $17: 12-14$ ) en word selfs 'n suigelingbesnydenis (Gen. 17:12). Kinders wat agt dae oud is, moet besny word. Ook aan die kindertjies word deur die sakrament van die besnydenis die waarborg gegee dat hulle deur geloof gered word. Hierdie waarborg ontvang hulle nie omdat hulle reeds glo nie. God gee die waarborg aan hulle wat nog glad nie glo of selfs kan glo nie.

Wel roep hierdie besnydenis die kindertjies tot geloof op. Die harte van die kindertjies moet besny word en dit is die werk van die Heilige Gees.

Uit die voortsetting van die volwassenebesnydenis in die kinder besny denis kan ons leer dat die volgorde: geloof - besnydenis wat vir Abraham by die verbondsluiting gegeld het ook omgekeer kan word: besnydenis - geloof.

Blykbaar is volgens die duidelike onderwysing van die Skrif die volgorde by die kinders juis omgekeerd: eers besnydenis en daarna geloof. Dit beteken nie dat die kinderbesnydenis van minder gehalte as eie volwassenebesnydenis is nie. Maar dit beteken wel dat die kinderbesnydenis om die besnydenis van die hart roep, dat die be snydenis vra om die geloof wanneer die kind opgroei.

In sy kommentaar op Rom. 4:11 wys Calvyn daarop dat die besnydenis by Abraham op die regverdiging volg maar dat by Isak die omgekeerde die geval is. In sy Kategismus skrywe Calvyn dat geloof en berou nie noodwendig altyd aan die doop hoef te gaan nie, maar dit word tog vereis van mense wat weëns hulle ouderdom tot albei in staat is (Simpson, 1981: 60).

Die unieke en die besondere van die besnydenis in die $\mathrm{Ou}$ Testament is dat daarin ' $n$ heenwysing geleë is na die heilsgebeure in Christus. Die geregtigheid waarheen die besnydenis wys, moet deur Christus volbring word. Maar tog kan Abraham en sy kinders reeds daarin deel.

Die besnydenishandeling self gaan nog met bloed gepaard. Die 
bloedgestalte wys op die heil in Christus. Die besnydenishandeling kom tot 'n einde nadat Christus sy bloed gestort het. Dan kom daar ' $n$ ander teken en seël waarby geen bloed meer hoef te vloei nie.

\section{DOOP EN GELOOF}

Die doop in die Nuwe Testament is soos die besnydenis in die $\mathrm{Ou}$ Testament op die heilsgebeure in Christus betrek. Die Christelike doop veronderstel die heilsgebeure met Christus. Deur middel van die doop word die gemeente opgeroep om deel te hê aan dit wat Christus deur sy lyding en sterwe en opstanding verwerf het.

Die doop in die Nuwe Testament is in die eerste plek 'n volwassenedoop. Dit behoef ons nie te verbaas nie, want in die Nuwe Testament kry ons voluit sendingsituasie. In Matth. 28 en Mark. 16 staan die opdrag om te doop in die breër raamwerk van die bevel om die evangelie te verkondig. Die doopbevel is ten nouste met die sendingbevel verbind.

Wanneer ons kyk na die doopopdrag in Mark. 16:16 dan sien ons dat aie eenheid van geloof en doop inderdaad daar sterk beklemtoon word. Die redding van die mens word verbind met sy geloof en sy doop, terwyl sy veroordeling met sy ongeloof gepaard gaan. Die eenheid van geloof en sy doop lê egter in Mark. 16:16 nie in hul onderlinge afhanklikheid nie, maar dit lê in die gesamentlike betrokkenheid van geloof en doop op die verkondiging van die evangelie (Mark. 16:15). In die verkondiging van die evangelie staan kruis en opstanding in die prediking van die evangelie aangebied (Joh. 2 123). Die doop is daarna die bevestiging van dit wat in die avangelie aangebied word. Ons mag die doop nie op een lyn stel met die geloof as middel om God se heil te ontvang nie. Saam met die geloof is die doop betrek op die verkondiging van die evangelie en op dit wat daarin aangebied word, naamlik die vergewing van sondes. Maar geloof en doop is elk op 'n eie manier betrek. Wat in die doop sigbaar verkondig, beteken en verseël word, kan alleen deur middel van die geloof ontvang word.

Dit lyk soms of die apostel Paulus doop en geloof op een lyn plaas. In Titus $3: 5$ is die doop die middel waardeur God ons red en volgens Ef. $2: 8$ is dit die geloof. In Gel. $2: 20$ word ons gekruisig wees saam met Christus verbind aan die geloof in die Seun van God, terwyl dieselfde heerlike heilswerklikheid in Kol 2:12 verbind word met die doop.

In sy kommentaar op Rom. $6: 4$ verduidelik Calvyn Paulus se merkwaardige spreke oor geloof en doop. Hy sê Paulus volgens sy gewoonte die wese en die vrug van die doop aan die uitwendige teken van die doop verbind, omdat hy hom in sy briewe tot gelowiges rig (Calvyn, 1950: 181). Ook al sê die Bybel met nadruk dat ons deur die doop in die sterwens- en lewensgemeenskap met Christus opgeneem is, dan beteken dit nog nie dat die doop ons red nie. Ons kan slegs gered word deur die heilsgebeure in Christus waarheen die doop verwys. Al word die doop die inlywing in Christus genoem, beteken dit hoegenaamd nie dat die Heilige Gees die werk van wedergeboorte en inlywing deur die doop bewerk nie. Dan gaan ons die werk van die Heilige Gees in die sakra- 
ment van die doop ten opsigte van sy werk deur die Woord verselfstandig.

Die doophandeling bring geen heil sonder geloof in Jesus Christus nie. Wanneer Paulus in Kol. $2: 12$ stel dat ons saam met Christus begrawe is in die doop dan wys hy direk daarna op die geloof wanneer hy skrywe dat ons saam opgewek is deur die geloof.

In die Skrif word aan ons verkondig dat ons alleen deur geloof aan die heilsgebeure in Christus deel het. Wat met Christus gebeur het, het met ons gebeur kragtens ons begrepenheid in Hom. Deur die geloof mag ons daarin deel. Wat aan ons in die Woord verkondig word, word in die doop uitgebeeld, beteken en verseël en gewaarburg. Daarom rig die doop ons geloof op die heilsgebeure in Christus. Die geloof word nie deur die doop in ons harte gewerk nie. Die doop is gegee om die geloof in ons harte te versterk, om ons te verseker dat ons in Christus ingelyf is.

Die doup is beslis nie 'n waarborg van ons geloof nie. Ons lees in die Nuwe Testament van gedooptes wat blykbaar tog nie ware gelowiges was nie (Hand. 8:9-24; 1 Tim. $1: 19,20 ; 2$ Tim. $4: 10$ ).

Daar is voorstanders van die volwessenedoop wat 'n vrysinnige geloof aanhang. Die doop as sodanig kan ons nie red nie. Daarom roep die doop om geloof.

Die Nuwe Testament wys baie duidelik op die onverbreekbare verhouding van geloof en doop. Dit is gelowiges wat in die Nuwe Testument gedoop word. Maar ook by die kinders wat gedoop word, bly die verhouding: geloof - doop van krag. Dit is egter nie nodig um die geloof by die kinders te veronderstel nie. Dit is selfs uitermate gevaarlik om by die doop iets te veronderstel wat nie daar is nie. Die hele verbondsopvoeding kom daardeur in gevaar.

By die kinderdoop gaan dit ook om geloof. Dit gaan egter by die kinderdoop nie primêr om die geloof in die kind nie maar om geloof RONDOM die kind (Douma, 1979: 117). Die kinderdoop is 'n doop van kınders van gelowige ouers, 'n doop vir kinders uit 'n huis waar die Koningskap van Christus erken, bely en geëerbiedig word. H. N. Ridderbos het dit in sy boek oor Paulus pragtig gestel: "We light, anders dan bij de volwassen, het criterium of het menslijk "aanknopingspunt" voor die kinderdoop niet in het persoonlijk geloof van de dopeling, maar in het toebehoren van de kinderen tot de ouders en het door hen gerapresenteerde levensverband" (Ridderbos, 1966: 462). Dit is nie nodig om persoonlike geloof by die kinders wat gedoop is te veronderstel nie. Juis omgekeerd word in de kinderdoop "de weg van het geloof voor hen te duidelijker geopen en de gehoorzaamheid van het geloof te nadrukkelijker van hen geëist" (Ridderbos, 1966: 462).

Deur kinders te doop voor hulle selfs Christus as Here kan erken en bely, veronagsaam die kerk nie die kind se geloofsbeslissing nie maar wil die kerk die kind juis help om tot geloof te kom. Die ouers en die kerk is deur opvoeding en kategese geroep om die kind te leer om sy doop te verstaan. Daarom is dit net gelowige ouers wat liulle kinders by die doopvont mag bring. Die geloof van 
die ouers en die doop van hulle kinders is altwee betrek op God se belufte-Woord.

In hierdie verband is ' $n$ opmerking van J. C. Coetzee so uiters belangrik: "Waar die tug in die kerk verwaarloos word, daar word die kiem geplant vir vraagtekens agter die kinderdoop. As ouers wat leef soos heidene, tugteloos in die kerk sou geduld word, dan groei die vraagtekens rondom die doop van hulle kinders. Laat ons dan ook die dwaling van die verwerping van die kinderdoop teenstaan deur in ons kerke erns te maak met die kerklike tug" (vgl. Floor, 1983: 121).

\section{WAT VERSEEL DIE DOOP?}

So kom ons ten slotte by die vraag wat ons eerste gestel het: wat verseël die doop presies? Is die doop die seël op ons geloof of verseël die doop die belofte van God? Omdat doop en geloof so uiters nou op mekaar betrek is, is dikwels die opvatting verkondig dat die doop die seël op ons geloof druk. Subjektivisties word die geloof tot 'n konstitutiewe element van die doop gemaak (Veenhof, $1949: 367$ ) of tot ' $n$ "medeconstituerende factor van die doop" (Ridderbos, 1966: 462). Volgens die Doperse Beweging is die doop die sakrament van dje wedergeboorte en van die geestelike reiniging en daarom is dit teen die rede om aan kinders sonder geloof en bekering die doop te bedien (Balke, 1973: 22).

Om die vraag te kan beantwoord wat die doop presies verseël, moet ons eers probeer vasstel wat die wese van die sakrament van die doop is.

Die Kategismus noem in Sondag 25 sakramente heilige sigbare waartekens en seëls. In die eerste plek is die sakrament van die doop 'n teken, 'n afbeelding of 'n illustrasie, 'n verduideliking om die belofte van die Evangelie vir ons te verduidelik sodat ons dit des te beter verstaan.

Wat God gespreek het en deur ons oor ons bereik, bring die Heilige Gees in die sakrament via die oog tot ons bewussyn. Onse goeie God doen dit vanweë ons stompsinnigheid en swakheid, so bely ons in Art. 33 NGB.

Die sentrale inhoud van die Evangelie, vergewing en lewe deur die kruisofier van Christus word in die teken van die water van die doop aan ons verduidelik. God se heil word in 'n paar vaste kontoure geteken. Dit is presies dieselfde heil wat ook in die Woord, in die belofte toegesê word.

Maar die sakramente is ook pande, seëls. Art. 33 noem die sakramente pande van die benignitas Dei, van die goedheid van God. God hei die sakıamente vir ons gegee om ons geloof te voed en te onderhou (Art. $33 \mathrm{NGB}$ ). Op watter wyse oefen die sakrament hierdie funksie uit?

Om hierdie vraag te kan beantwoord moet ons daarop let dat in die sakrament twee dinge goed onderskei moet word: die uiterlike teken en die saak wat deur die teken afgebeeld word. Met betrekking tot die doop is dit die water en die afwassing van die sondes met daarmee saam die vernuwing van die lewe. Hierdie twee sake: die teiken en die afwassing van die sonde mag nie van mekaar ge- 
skei word nie. Wanneer die heilige doop bedien word, word saam met die teken ook dit wat deur die teken afgebeeld word aan die dopeling uitgereik. In die doophandeling is teken en dit wat deur die teken afgebeeld word onlosmaaklik met mekaar verbonde. Ons noem dit die unio sacramentalis. Omdat in die sakrament hierdie eenheid altyd ' $n$ feit is daarom die doop die afwassing van die sondes genoem word.

Omdat teken en dit wat deur die teken uitgebeeld word in die sakrament steeds met mekaar verbind is, kan die geloof die vergewing van sondes en die vernuwing van die lewe deur die gebruik van die sakrament ontvang. Wanneer die doop gelowig gebruik vord dan word ons verseker van die afwassing van ons sondes vanweë die heerlike werklikheid dat ons saam met Christus gesterf en opgestaan het. Daarom kan Art. 34 NGB sê dat die doop nie alleen nuttig is solank as die water op ons is en ons die water ontvang nie maar ook vir die ganse tyd van ons lewe.

Wat is egter die geval wanneer die sakrament nie deur waaragtige geloof ontvang word nie, wanneer daar volhardende ongeloof is by diegene wat die sakrament gebruik? Deur ongelowige gebrujk van die sakrament word die wese van die sakrament hoegenaamd nie aangetas nie. Die goddelose, so sê Art. 35 NGB ontvang wel die sakrament, maar hy ontvang dit tot sy verdoemenis Hy ontvang nie Christus, hy ontvang nie die waarheid van die sakrament nie, omdat dit wat in die teken uitgebeeld word alleen in die geloof ontvang kan word.

Calvyn skrywe in sy Kategismus dat goddelose mense wel die gawes van God wat in die sakramente aan hulle voorgesit word, tot niet maak, in soverre dit hulle raak, maar hulle veroorsaak nie daarmee dat sy werking nie nog in die sakrament bly nie (Simpson, 1981: 57). Volgens Calvyn bly die eie natuur en krag in die sakrament ook al word dit in ongeloof gebruik (Veenhof, 1949: 193).

In sy kommentaar op Eseg. 20:20 het Calvyn die beroemde woorde geskrywe: Ons moet vashou dat daar 'n wedersydse verhouding is tussen geloof en sakrament. Die sakramente ontvang hulle uitwerking uit die geloof. Die sakramete behou altyd hulle natuur. Die doop is die bad van die wedergeboorte ook al is die hele wereld ongelowig. Ons kan die genade wat ons aangebied word nie geniet en van die geestelike sake wat altyd dieselfde bly kan ons die uitwerking daarvan nie ontvang nie, wanneer ons deur ongeloof ontheilig wat God tot ons heil gewy het. (vgl. Greijdanus, s.j.: 10).

In samesprekings wat Luther en Bucer in 1536 oor die nagmaal gehou het, het hulle juis oor hierdie punt ooreenstemming bereik. Hulle het saamgestem dat ook die onwaardiges in die heilige nagmaal die liggaam en bloed van Christus waaragtig gegee (dargereicht) word.

Hulle ontvang dit egter tot hulle oordeel, omdat hulle dit sonder boete en geloof ontvang (Veenhof, 1949: 361). Christus en sy weldade kan alleen in die geloof ontvang word. God kom met sy belofte tot alle bondelinge. Hulle het reg gekry op Christus en sy weldade. Selfs op die gawe van die Heilige Gees wat die geloof werk. En dit alles word in die doop verseël. Maar alle toeseggings van God 
word slegs deur geloof ontvang. Deur geloof ontvang die gedoopte wat hy kragtens die verbond van God reg op het.

Die Kategismus sê in Sondag 25 dat God in die sakramente die beloftes van die evangelie verseël. Ons moet hierby altyd in gedagte hou dat daar verskil is tot belofte en die vervulling of realisering van die belofte, belofte in toesegging en belofte in vervulling (Greijdanus, s.j.: 16). God kom ook in die sakrament met sy heilstoesegging. Deur die geloof wat die Heilige Gees in die hart werk vind die heilstoeëiening plaas. Wanneer die belofte met die beloofde goed geïdentifiseer word (Veenhof, 1949: 356) en ons die onderskeid tussen 'n voorwaardelike heilstoesegging en 'n onvoorwaardelike heilstoeëiening nie meer raak sien nie (Berkouwer, 1940: 135, 136) dan beland ons by Rome of by die Anabaptiste.

\section{SAAMVATTING}

Daar is wel beweer dat met betrekking tot die kinderdoop die Reformatore nog vasgevang was in die Roomse tradisie, maar wie so redeneer het die teologie van die Reformatore nie reg verstaan nie. Die doop is nie die antwoord van die bekeerde mens op die roeping van God soos die Anabaptiste dit stel. God handel in die doop en nie die mens nie, ook nie God en die mens saam nie, maar alleen God.

Wie die kinderdoop verwerp maak Jesus los van die Ou Testament, bring 'n ongeoorloofde skeiding tot stand tussen die volk van God in die Ou Testament en die gemeente van Jesus Christus in die Nuwe Testament. Die eenheid van die Skrif word prysgegee en die deur word oopgemaak vir geesdrywery.

Die verwerping van die kinderdoop sny diep in die lewe in. Dit raak die verhouding tussen ouers en kinders.

Wie die kinderdoop verwerp bou nie op die belofte van God nie, maar hy bou in staat en kerk, familie en skool 'n gebou wat op menslike willekeur gebou is (de Zuervain, 1934: 263).

\section{BIBLIOGRAFIE}

BALKE, W., Calvijn en de doperse radikalen, 1973.

BEASLEY-MURRAY, G. R., Baptims in the New Testament, 1979.3

BERKOUWER. G. C., De Strijd om het Roomsch Katholiekc dogma, 1940.

CALVYN, J., Uitlegging van de zendbrief van Paulus aan de Romeinen, Vert.

D. J. de Groot 1950. 
DE ZUERVAIN, A., Der theologische Gehalt von Calvins Tauflehre, Reformierte Kirchenzeitung, 84 (1934).

DOUMA, J., Geloof en doop, in: De Reformatie, Jaarg. 55, nr. 8,24 Nov. 1479.

FLCOR, L., Die Heilige Doop in die Nuwe Testament, 1983.

FLUSSER, D., Die Sakramente und das Judentum, in: Judaica, Beitrage zum Verständnis des judischen Schicksals in Vergangenheit und Gegenwart, 39e jaarg., Heft 1, Marz 1983.

FOLIVER, S., Christian Biptims, A reformed reply to a reformed PaedobapLIst, 1968.

GRAAFLAND, Het vaste verbond, 1978.

GREIJDANUS, S., Korte bespreking van het praeadvies van commissie I, s.j. KOOPMANS, J. J., De Nederlandse Geloofsbelijdenis, 1939.

POLMAN, A. D. R., Onze Nederlandsche Geloofsbelijdenis, s.j.

RIDDERBOS, H. M., Paulus, ontwerp van zijn theologie, 1966.

SIMPSCN, H. W., Calvyn de kategismus, 1981.

VEENHOF, C., Om de "Unica CATHOLICA", 1949.

WOLF,H. H., Die Eeinheit des Bundes. Das Verhăltnis von Allum und Neuem Testament bei Calvin, 1958. 